\title{
The TOB/SAM complex composition in mitochondria of Dictyostelium discoideum during progression from unicellularity to multicellularity*
}

\author{
Monika Mazur'1, Małgorzata Wojtkowska', Marcin Skalski', Małgorzata Słocińska² \\ and Hanna Kmita1日
}

1Institute of Molecular Biology and Biotechnology, Department of Bioenergetics, Faculty of Biology, Adam Mickiewicz University, Poznań, Poland; '2Department of Animal Physiology, Faculty of Biology, Adam Mickiewicz University, Poznań, Poland

Despite its complex life cycle including unicellular and multicellular stages, the slime mold Dictyostelium discoideum, a well-known model in biomedical research, has not been used as a model organism in studies on mitochondrial import, including its significance in cellular processes. Moreover, data concerning mitochondrial protein import machinery in $D$. discoideum mitochondria is limited and nothing is known about the impact of that machinery on slime mold life cycle. Here, we focused on the TOB/SAM (topogenesis of the mitochondrial outer membrane $\beta$-barrel proteins/sorting and assembly machinery) complex. This complex is localized in the mitochondrial outer membrane and is indispensable for the formation of metabolite exchange and protein import pathways in the membrane, and substantially contributes to the regulation of mitochondrial morphology and distribution. Furthermore, the available data suggests that the TOB/SAM complex variants differ between mitochondria of multicellular and unicellular eukaryotes. Therefore, we decided to determine these variants of the TOB/SAM in mitochondria of $D$. discoideum progressing from single cells to early multicellular stages, when the cells stream together to form a multicellular organism. The results revealed two complex variants of the TOB/SAM complex of about 160 and $600 \mathrm{kDa}$ molecular weight, present in mitochondria of $D$. discoideum cells at the studied stages. The discussed complex variants resemble the ones that have been already detected for the yeast Saccharomyces cerevisiae, fungus Neurospora crassa and human cells, and one of investigated variants differentiates unicellular and initial multicellular stages of the D. discoideum life cycle.

Key words: mitochondria, protein import, TOB/SAM complex, Dictyostelium discoideum

Received: 14 March, 2019; revised: 17 July, 2019; accepted: 16 September, 2019; available on-line: 12 November, 2019

๑e-mail: kmita@amu.edu.pl

*Acknowledgements of financial support:

The costs of the article published as a part of the 44th FEBS Congress Kraków 2019 - From molecules to living systems block are financed by the Ministry of Science and Higher Education of the Republic of Poland (Contract 805/P-DUN/2019).

This project was supported by the National Science Centre (Poland) project (grant no. 2012/05/N/NZ3/00293), and the "KNOW RNA Research Centre in Poznan" (grant no. 01/KNOW2/2014).

Abbreviations: MICOS, mitochondrial contact site and cristae-organizing system; TOB/SAM, topogenesis of the mitochondrial outer membrane $\beta$-barrel proteins/sorting and assembly machinery; TOM, translocase of the outer membrane; XP 641975.1, Mdm10; XP_642798.1, Tom40; XP_642848.1, metaxin; XP_646058.1, Tob55/ Sam50; XP_646782.1, mitofilin/Mic60

\section{INTRODUCTION}

The slime mold Dictyostelium discoideum is recognized by the National Institute of Health (NIH) as a model of particular value in biomedical research, including mitochondrial diseases (www.nih.gov/science/models). The reason is high homology of $D$. discoideum protein sequences to human proteins (e.g. Eichinger et al., 2005) and its complex life cycle (see Fig. 1). The latter includes different unicellular and multicellular stages which provides a possibility to study cellular processes at intracellular and intercellular levels. This also applies to the mitochondrial protein import process being crucial for the mitochondrial biogenesis and functioning. Most of the mitochondrial proteins are synthesized in the cytosol and therefore have to be imported into various mitochondrial subcompartments.

The mitochondrial outer membrane contains two main import complexes, i.e. the TOM complex (translocase of the outer membrane) and the TOB/SAM complex (topogenesis of the mitochondrial outer membrane $\beta$-barrel proteins/sorting and assembly machinery). The TOM complex recognizes, sorts and translocates most of the mitochondrial precursor proteins from the cytosol, whereas the TOB/SAM complex participates in the TOM complex assembly and inserts $\beta$-barrel proteins into the outer membrane after translocation of these

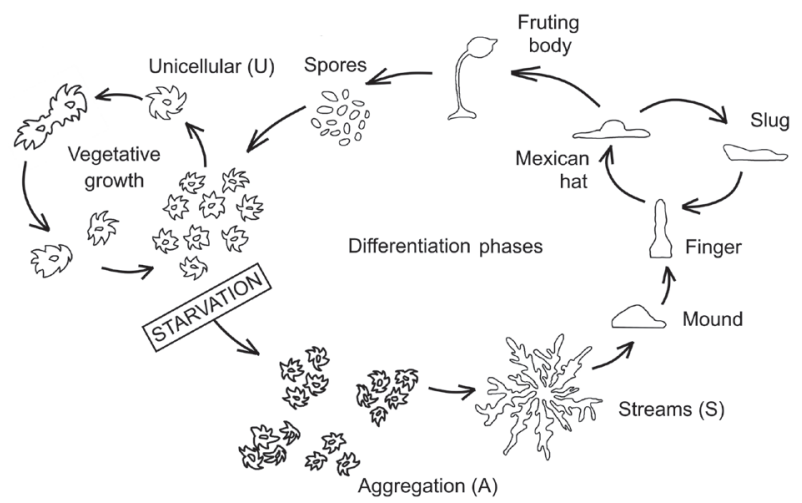

Figure 1. Life cycle of $D$. discoideum.

The vegetative phase ( $U$, unicellular) ceases when food is depleted (bacteria in the soil). Single cells enter differentiation phase, also termed a social phase. After passing the early multicellular stages ( $\mathrm{A}$, aggregation; $\mathrm{S}$, streams) cells aggregate and form a motile slug, which ultimately develops into a fruiting body dispersing spores to new feeding sites. 
proteins into the intermembrane space by the TOM complex (reviewed by Endo \& Yamano, 2010; Neupert, 2015; Höhr et al., 2018; Pfanner et al., 2019). The proteins are exemplified by mitochondrial porin required for metabolite transport, as well as channel forming subunits of the TOM and TOB/SAM complexes, Tom40 and Tob55/Sam50, respectively (Höhr et al., 2018). Thus, the TOB/SAM complex is essential for formation of the metabolite exchange and protein import pathways in the mitochondrial outer membrane and substantially contributes to regulation of mitochondrial functioning.

In studies on the function and interplay of mitochondrial protein import complexes, the yeast Saccharomyces cerevisiae is mainly applied as a model organism (e.g. Sokol et al., 2014; Neupert, 2015). The S. cerevisiae TOB/ SAM complex is proposed to consist of three main subunits, i.e. Tob55/Sam50, Tob38/Sam35 (Tom38), and Tob37/Sam37 (Tom37, Mas37). However, in the case of other eukaryotes, smaller or bigger differences in the complex subunits have been reported. For example, the animal TOB/SAM complex contains metaxin-2 as a counterpart of Tob38/Sam35, as well as metaxin-1 and metaxin-3 as counterparts of Mas37/Sam37 (Sokol et al., 2014), whereas the subunits predicted for the complex of the slime mold $D$. discoideum include Tob55/ Sam50 and metaxin as a sole receptor subunit (Buczek et al., 2016; Wojtkowska et al., 2017). It is assumed that the monomeric form of the TOB/SAM complex, composed of the main subunits, has molecular weight of $160-250 \mathrm{kDa}$, depending on the studied organism (e.g. Kozjak-Pavlovic et al., 2007; Yamano et al., 2010; Ott et al., 2012; Neupert, 2015), although other forms of the complex are also detected due to complex interaction with proteins that are also subunits of other complexes, including the TOM complex (Qiu et al., 2013; Wenz et al., 2015), endoplasmic reticulum-mitochondria encounter structure complex (Kornmann et al., 2009; Yamano et al., 2010; Flinner et al., 2013) and the MICOS (mitochondrial contact site and cristae-organizing system) complex (e.g. Rampelt et al., 2017). The available data indicate that detected forms of the TOB/SAM complex may differ between multicellular organisms, represented by human cells (Kozjak-Pavlovic et al., 2007; Xie et al., 2007; Ott et al., 2012), Neurospora crassa (Klein et al., 2012; Lackey et al., 2011) and unicellular ones, e.g. S. cerevisiae (Waizenegger et al., 2004; Yamano et al., 2010). This may imply a correlation between the TOB/SAM complex and multicellularity. Here, we present verification of this assumption by analysis of the TOB/SAM complex forms in mitochondria of $D$. discoideum progressing from single cells to early multicellular stages when the cells aggregate and then stream together to form a multicellular organism.

\section{MATERIALS AND METHODS}

Dictyostelium discoideum growth conditions and the studied life cycle stages. $D$. discoideum is a social amoeba whose life cycle consists of vegetative growth and a differentiation phase (Flowers et al., 2010; Czarna et al., 2010). The unusual differentiation process starts from aggregation of single cells, which is triggered by nutrient depletion. Then, the developing multicellularity reaches the stage of streams formed by the aggregating cells and followed by a slug formation that culminates as a fruiting body (top of the stalk) consisting of spores (Fig. 1).

The axenic strain AX2 of $D$. discoideum was kindly provided by Prof. Michael Schleicher from Ludwig Maximil- ian University of Munich, Germany. D. discoideum cells were cultured in axenic growth medium containing $1 \%$ $\mathrm{w} / \mathrm{v}$ proteose peptone, $0.5 \% \mathrm{w} / \mathrm{v}$ yeast extract, $0.45 \%$ $\mathrm{w} / \mathrm{v}$ D-glucose, $0.09 \% \mathrm{w} / \mathrm{v} \mathrm{Na} \mathrm{NPO}_{4}$ and $0.23 \% \mathrm{w} / \mathrm{v}$ $\mathrm{KH}_{2} \mathrm{PO}_{4}$. Cell culture was propagated in $850 \mathrm{ml}$ of the axenic growth medium at $19^{\circ} \mathrm{C}$, on a Certomat $\mathrm{MO}$ rotary shaker at $90 \mathrm{rpm}$. Cells were cultured exponentially till the density of approximately $2.0-3.0 \times 10^{6}$ cells $/ \mathrm{ml}$ (the doubling time of 10-11 h). These cells constituted the unicellular (U) stage. Cells at aggregation (A) and stream (S) stages were obtained by placing $U$ stage cells into Petri dishes $\left(1.7 \times 10^{6}\right.$ cells $\left./ \mathrm{cm}^{2}\right)$ with a solid starvation medium called Development Buffer (DB) and containing $5 \mathrm{mM} \mathrm{Na}_{2} \mathrm{HPO}_{4}, 5 \mathrm{mM} \mathrm{KH} \mathrm{PO}_{4}, 1 \mathrm{mM} \mathrm{CaCl}, 2 \mathrm{mM}$ $\mathrm{MgCl}_{2}, \mathrm{pH} 6.5$ and $1.25 \% \mathrm{w} / \mathrm{v}$ agar (Fey et al. 2007). The cells were harvested after $\sim 23 \mathrm{~h}$ for A stage, and $\sim 25 \mathrm{~h}$ for $\mathrm{S}$ stage. The presence of U, A and S stages was confirmed by Nikon Eclipse TE 2000-U microscope. The images were obtained by Nikon DS-1QM camera, and processed by the NIS Elements A 3.10 software.

Immunofluorescent staining. Intact cells were incubated with $200 \mathrm{nM}$ MitoTracker ${ }^{\mathrm{TM}}$ Red FM (Invitrogen), a red-fluorescent dye, which stains mitochondria due to accumulation dependent upon the inner membrane potential, for $1 \mathrm{~h}$ at $37^{\circ} \mathrm{C}$. Cells were then washed in PBS and fixed in $4 \%$ paraformaldehyde solution (in PBS) for $20 \mathrm{~min}$ at room temperature, seeded on poly L-lysine slides and allowed to dry completely. The cells were subsequently fixed with ice cold methanol and permeabilized with cold acetone for $5 \mathrm{~min}$. Subsequently, the fixed cells were blocked in 5\% BSA at room temperature for $1 \mathrm{~h}$ and afterwards incubated for $1 \mathrm{~h}$ with antibodies raised against Tob55/Sam50 at a dilution of 1:100 in PBS buffer with $5 \%$ BSA, at room temperature. Next, the cells were washed in phosphate buffered saline (PBS), and incubated for $1 \mathrm{~h}$ at room temperature with goat-anti-rabbit $\operatorname{IgG}$ conjugated to fluorescein isothiocyanate (FITC) (Santa Cruz Biotechnology) at a dilution of 1:100 (Slocinska et al., 2011). Finally, samples were analyzed under Nikon Eclipse TE 2000-U fluorescence microscope. The images were obtained with a Nikon DS-1QM camera, and processed by the NIS Elements A 3.10 software.

Mitochondria isolation. Cells from U, A and S stages were centrifuged at $600 \times \mathrm{g}$ for $5 \mathrm{~min}$ and then washed twice in phosphate medium A $\left(14.5 \mathrm{mM} \mathrm{KH_{2 }} \mathrm{PO}_{4}\right.$, $5 \mathrm{mM} \mathrm{Na}_{2} \mathrm{HPO}_{4}, \mathrm{pH}$ 6) by centrifugation at $600 \times g$ for 5 min. Next, the cells were homogenized in medium B (0.38 M sucrose, $20 \mathrm{mM}$ Tris-Cl, $0.5 \mathrm{mM}$ EDTA, $1 \%$ defatted bovine serum albumin [BSA], $\mathrm{pH}$ 7.5) using glass/Teflon homogenizer and centrifuged at $860 \times g$ for $5 \mathrm{~min}$. Supernatant was centrifuged at $10000 \times g$ for $15 \mathrm{~min}$. The obtained pellet was suspended in medium C $(0.38 \mathrm{M}$ sucrose, $20 \mathrm{mM}$ Tris-Cl, $0.5 \mathrm{mM}$ EDTA, $0.6 \%$ defatted BSA, $\mathrm{pH} 7.2$ ) and centrifuged at $860 \times g$ for $5 \mathrm{~min}$ to remove remaining cells. Supernatant was centrifuged at $10000 \times g$ for $10 \mathrm{~min}$, mitochondrial pellet was suspended in medium $\mathrm{D}(0.38 \mathrm{M}$ sucrose; $20 \mathrm{mM}$, Tris-Cl, pH 7.2) and centrifuged at $10000 \times g$ for $15 \mathrm{~min}$. After this step, the mitochondrial pellet was suspended in medium D and used for further analysis. Efficiency of the mitochondria isolation procedure varied depending on the stage, from $1.5 \mathrm{mg}$ of mitochondrial proteins per $1 \mathrm{~g}$ of cells at $\mathrm{A}$ and $\mathrm{S}$ stages, to $4.5 \mathrm{mg}$ of mitochondrial proteins per $1 \mathrm{~g}$ of cells at the U stage. All media used for mitochondria isolation were ice cold and centrifugation procedures were carried out at $4^{\circ} \mathrm{C}$.

Protein electrophoresis. Blue Native Polyacrylamide Gel Electrophoresis (BN-PAGE) was performed accord- 
ing to Witting and others (Witting et al., 2012). Mitochondria $(100 \mu \mathrm{g})$ were solubilized in a buffer containing 0.1 M EDTA, $50 \mathrm{mM} \mathrm{NaCl}, 10 \%$ glycerol, $20 \mathrm{mM}$ Tris, $1 \mathrm{mM}$ PMSF, $\mathrm{pH} 7.4$ and $1.25 \%$ digitonin (Sigma-Aldrich) for $20 \mathrm{~min}$ at $4^{\circ} \mathrm{C}$, and centrifuged for $50 \mathrm{~min}$ at $14000 \times \mathrm{g}$ and $4^{\circ} \mathrm{C}$. Aliquots of solubilized mitochondria were mixed with Serva Sample Buffer for Blue Native $(2 \times$ conc.) and loaded on the $6-13 \%$ native gradient gel (prepared in $1.5 \mathrm{M} \varepsilon$-amino-n-caproic acid and $0.15 \mathrm{M}$ Bis-Tris, pH 7). Sodium Dodecyl Sulfate Polyacryl mide Gel Electrophoresis (SDS-PAGE) was performed according to Laemmli (Laemmli, 1970). SDS-PAGE and BN-PAGE gels were stained with Serva Coomassie Brilliant Blue G-250. To perform Western blot immunodecoration proteins separated by BN-PAGE were transferred to PolyVinylidene DifFluoride (PVDF) membrane (Millipore) and by SDS-PAGE to nitrocellulose membrane. After immunodecoration proteins were visualized by the Lumi-Light Western Blotting Substrate (Roche).

Mass spectrometry. Protein bands indicated by Western immunoassays were analyzed by liquid chromatography coupled to tandem mass spectrometry (LC-MS/MS) performed in the Mass Spectrometry Laboratory (Institute of Biochemistry and Biophysics, Polish Academy of Sciences Warsaw, Poland). The gel bands were subjected to digestion by a standard procedure where trypsin was used (Promega, Madison, WI, USA). Peptide mixtures were separated by LC-MS/MS prior to molecular mass measurements using LTQ-FTICR on Orbitrap Velos mass. The RP-18 precolumn and nano-HPLC RP-18 column was used for separation of peptides obtained by digestion. Raw data was processed by the Mascot search against the NCBI database (www.ncbi.nig.gov) restricted to Eukaryota and $D$. discoideum AX2 strain. Peptide mass tolerance was \pm 20 ppm.

Other methods. Protein concentration was measured by Bradford method, with BSA as a standard (Bradford, 1976). Amino acid sequence of mitofilin/Mic60 was predicted using the blastp algorithm (https://blast.ncbi.nlm. nih.gov) and the Pfam model (http://pfam.xfam.org).

Antibodies. The antibody against $D$. discoideum Tob55/ Sam50 protein, supplied by the Pineda company (Berlin, Germany), was directed against the 20 amino acid N-terminal sequence $\left(\mathrm{NH}_{2}\right.$-DDDDIKIKFVNIKSENVFLC$\mathrm{CONH}_{2}$ ). The delivered serum was purified using the modified sulfhydrylagarose (Pierce). The first step of purification was binding of the peptide used for immunization with the SulfoLink Coupling Resin. This was done in coupling medium $(50 \mathrm{mM}$ Tris, $5 \mathrm{mM}$ EDTA-Na; pH 8.5), using $1 \mathrm{ml}$ of peptide per $1 \mathrm{ml}$ of the resin, for $30 \mathrm{~min}$ at room temperature. The coupling efficiency was determined by spectrophotometrical $(\lambda=280 \mathrm{~nm})$ estimation of peptide non-coupled fraction concentration. Next, the nonspecific binding sites on the resin were blocked by adding 1 $\mathrm{ml}$ of $50 \mathrm{mM}$ cysteine solution to the column at room temperature for 15 minutes with shaking and without mixing for an additional 30 minutes. Afterwards, the column was washed by six resin-bed volumes of 1 $\mathrm{M} \mathrm{NaCl}$ and stored in the PBS medium. For purification of the antibody against Tob55/Sam50, the column was incubated with $2 \mathrm{ml}$ of serum overnight at $4^{\circ} \mathrm{C}$ and then washed with PBS. Finally, samples were eluted using $100 \mathrm{mM}$ glycine (pH 3.0) and immediately neutralized by adding $50 \mu \mathrm{L}$ of neutralization buffer (1 M Tris-Cl, pH 8.8). The elution efficiency was estimated spectrophotometrically $(\lambda=280 \mathrm{~nm})$. Samples of interest were desalted in the presence of PBS and stored

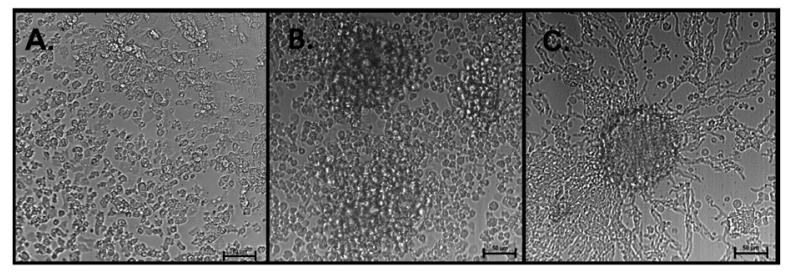

Figure 2. The early multicellular stages of the $D$. discoideum life cycle.

Samples were analyzed with a Nikon Eclipse TE 2000-U light microscope. The images were obtained with a Nikon DS-1QM camera. U, unicellular stage; $A$, aggregation stage; $S$, streams.

at $-20^{\circ} \mathrm{C}$. The antibody against human metaxin- 1 protein was purchased from Sigma-Aldrich.

\section{RESULTS}

\section{The early multicellular stages of the $D$. discoideum life cycle}

To monitor changes of the TOB/SAM complex variants during transition from unicellularity to multicellularity, three stages: unicellular (U), aggregation (A) and streams (S) were selected. The occurrence of those stages in the $D$. discoideum life cycle is depicted in Fig. 1 and was confirmed by light microscopy as shown in Fig. 2. The starvation of $U$ stage cells resulted in the A stage (Fig. 2B), characterized by the presence of irregular clusters of various amounts of cells. Further starvation of cells has led to the S stage (Fig. 2C), formed by cells in an aggregation process, and followed by mound formation (Fig. 1). As shown in Fig. 2C, cells at the S stage gathered by migrating in organized streams, finally producing a structure similar to a star or a flower.

\section{Detection of the TOB/SAM complex main subunits in mitochondria of unicellular and early multicellular stages}

As we had previously predicted the main subunits of the $D$. discoideum TOB/SAM complex using available genomic and transcriptomic sequences (Wojtkowska et al., 2012; Buczek et al., 2016), we decided to confirm the presence of the Tob55/Sam50 and metaxin subunits at a protein level. The designed polyclonal antibody against Tob55/Sam50 (Materials and Methods) was used to confirm the presence of Tob55/Sam50 in mitochondria of intact cells at the studied stages (Fig. 3A), as well as in mitochondria isolated from these cells (Fig. 3B). As shown in Fig. 3A, staining of mitochondria with Mito'Tracker ${ }^{\text {TM }}$ Red FM (Fig. 3A.1) and subsequent incubation with the antibody against Tob55/Sam50 (Fig. 3A.2) co-localized in the merged image (Fig. 3A.3), indicating the presence of Tob55/Sam50. The protein was also detected in separated mitochondrial proteins by Western immunoassays (band ca. 45 kDa; Fig. 3B). Moreover, signals obtained with the antibody against Tob55/Sam50 for mitochondria isolated from cells at the studied stages were confirmed by LC-MS/MS using the corresponding band in SDS-PAGE gels (Table S1 at https://ojs. ptbioch.edu.pl//). The presence of metaxin was also confirmed in mitochondria isolated from cells at the studied stages by application of a commercially available human metaxin-1 antibody (Fig. 3B), as well as by LC-MS/MS using $\mathrm{t}$ he corresponding band in SDS-PAGE gels (Table 

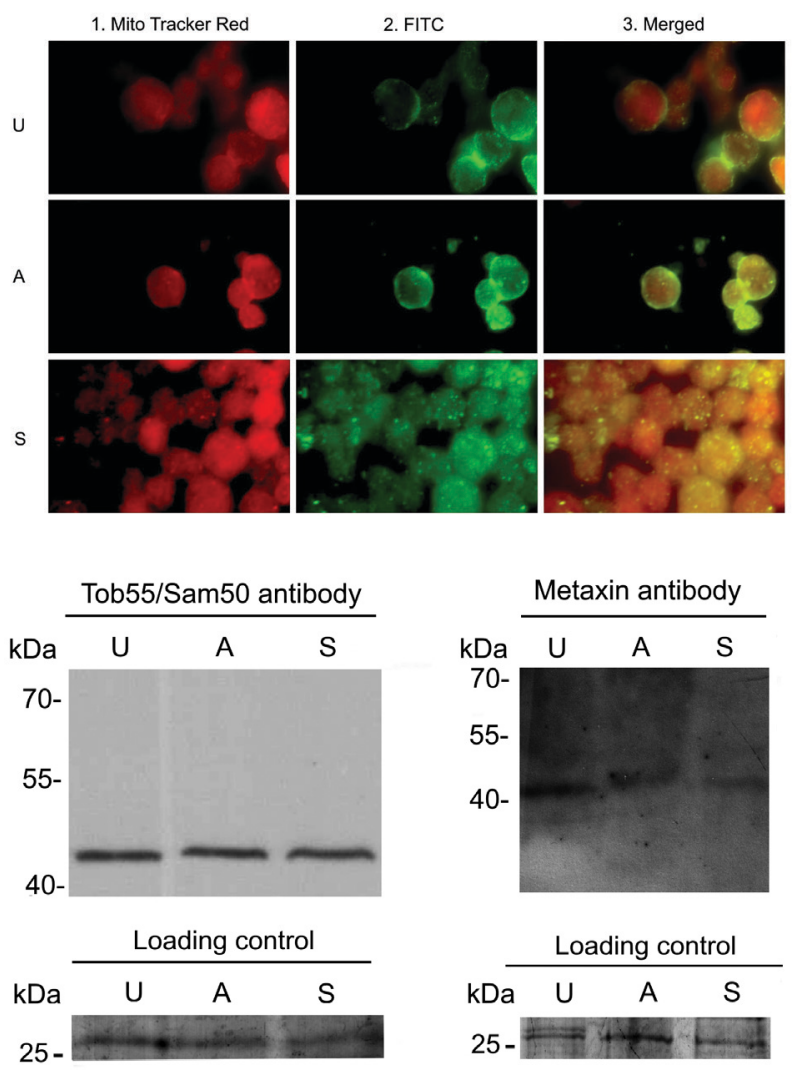

Figure 3. Detection of the $D$. discoideum TOB/SAM complex main subunits at a protein level.

(A) Immunofluorescence localization of Tob55/Sam50. The localization was performed for single cells $(\mathbf{U})$, as well as cells from the early developmental stages (U, A and S). Panel 1, staining with MitoTracker ${ }^{\mathrm{TM}}$ Red FM (Invitrogen) to visualize mitochondria; Panel 2, incubation with goat anti-rabbit lgG recognizing the antibody against Tob55/Sam50 protein and conjugated to fluorescein isothiocyanate (FITC); Panel 3, the merged image. Specimens were analyzed with a Nikon Eclipse TE 2000-U fluorescence microscope. Images were obtained with a Nikon DS-1QM camera. (B) Immunodetection of Tob55/Sam50 and metaxin among mitochondrial proteins isolated from the cells described in (A), separated by $12 \%$ SDS-PAGE and immunodecorated by respective antibodies after Western blotting. The results shown in $(\mathbf{A})$ and $(\mathbf{B})$ are typical for 3 independent experiments. Loading control - a $25 \mathrm{kDa}$ protein band shown on part of a Coomassie stained gel.

S1 https://ojs.ptbioch.edu.pl/). The molecular weight of this protein was estimated to be at about $46 \mathrm{kDa}$.

\section{Estimation of the TOB/SAM complex variants in} mitochondria of unicellular and early multicellular stages

The application of western immunoassay on $\mathrm{BN}$ blots with antibodies against Tob55/Sam50 and human
Table 1. Components of the TOB/SAM complex variants from the $\mathrm{U}, \mathrm{A}$ and $\mathrm{S}$ developmental stages in $D$. discoideum mitochondria

\begin{tabular}{lll}
\hline \multicolumn{3}{c}{ Subunits detected by } \\
\hline app. molecular weight & immunodetection & LC-MS/MS \\
\hline $600 \mathrm{kDa}$ & $\begin{array}{l}\text { Tob55/Sam50; } \\
\text { metaxin }\end{array}$ & $\begin{array}{l}\text { Tom40; } \\
\text { mitofilin }\end{array}$ \\
\hline $160 \mathrm{kDa}$ & Tob55/Sam50 & $\begin{array}{l}\text { Mdm10; } \\
\text { mitofilin }\end{array}$ \\
\hline
\end{tabular}

metaxin-1 to detect possible variants of the TOB/SAM complex in mitochondria isolated from cells at U, A and $\mathrm{S}$ stages, indicated the presence of two distinct forms of the complex independently of the studied stage (Table 1). Their molecular weights were estimated to be at about 600 and $160 \mathrm{kDa}$. Importantly, metaxin was detected in the larger complex only. Other putative partners or subunits of the TOB/SAM complex variants could not be detected by immunoassays due to the lack of specific antibodies. Therefore, we applied LC-MS/MS to identify them. As a result, additional proteins were identified. In the $600 \mathrm{kDa}$ complex, Tom40 (Wojtkowska et al., 2012) and mitofilin/Mic60 were found (Table 2), the latter for the first time in this study (Table S2 at https://ojs.ptbioch.edu.pl/). Importantly, mitofilin/Mic60 was detected only at the $U$ stage. A putative nucleotide sequence of mitofilin/Mic60 was found by blastp and Pfam model (Fig. S1 at https://ojs.ptbioch.edu.pl/), and used to detect the mitofilin domain (Yang et al., 2012; Ott et al., 2015) in a putative sequence obtained by LC-MS/MS. Interestingly, in the $160 \mathrm{kDa}$ complex, we detected Mdm10, but not the Tom40 protein (Table 1). Notably, $\mathrm{Mdm} 10$ had been previously predicted in $D$. discoideum by bioinformatics analysis (Buczek et al., 2016) but at a protein level it was confirmed for the first time in this study (Table S2 at https://ojs.ptbioch.edu.pl/).

\section{DISCUSSION}

The available data on different variants of the TOB/ SAM complex detected for unicellular ( $S$. cerevisiae) and multicellular (N. crassa and human cells) organisms suggests a correlation between this complex and the level of organism organization (Table 3). D. discoideum cells progressing from the single cell (U) stage to early multicellular (A and S) stages, when single cells aggregate and then stream together forming a multicellular structure, constitute a useful model to study a shift between unicellularity and multicellularity. However, the assumed relationship is not confirmed by the obtained results as they indicate that the TOB/SAM complex variants do not differ between the stages. Namely, the same two variants of the complex of molecular weight of about 600 and $160 \mathrm{kDa}$ are present in mitochondria isolated from cells at these stages (Fig. 4).

Table 2. The TOB/SAM complex subunits identified at the protein level in mitochondria of $D$. discoideum cells progressing from unicellullarity to early multicellularity

\begin{tabular}{|c|c|c|c|}
\hline \multirow{2}{*}{ Identified protein } & \multirow{2}{*}{ Accession number } & \multicolumn{2}{|l|}{ Proteins identified at } \\
\hline & & the genome/transcriptome level & the protein level \\
\hline Tob55/Sam50 & XP_646058.1 & Wojtkowska et al., 2012 & this study \\
\hline Tom40 & XP_642798.1 & Wojtkowska et al., 2012 & Wojtkowska et al., 2015 \\
\hline metaxin & XP_642848.1 & Buczek et al., 2016 & this study \\
\hline Mdm10 & XP_641975.1 & Buczek et al., 2016 & this study \\
\hline mitofilin/Mic60 & XP_646782.1 & this study & this study \\
\hline
\end{tabular}


Table 3. Variants of the TOB/SAM complex of S. cerevisiae, N. crassa, human and D. discoideum mitochondria

\begin{tabular}{|c|c|c|c|}
\hline $\begin{array}{l}\text { S. cerevisiae } \\
\text { (Qiu et al., 2013) }\end{array}$ & $\begin{array}{l}\text { N. crassa } \\
\text { (Klein et al., 2012) }\end{array}$ & $\begin{array}{l}\text { Human } \\
\text { (Ott et al., 2012) }\end{array}$ & $\begin{array}{l}\text { D. discoideum } \\
\text { this study }\end{array}$ \\
\hline $\begin{array}{l}\mathbf{6 5 0} \text { kDa supercomplex } \\
\text { TOB/SAM: Tob55/Sam50; } \\
\text { Sam37, Sam35; } \\
\text { TOM: Tom40, Tom22, Tom20, Tom70, } \\
\text { Tom6, Tom7, Tom5 } \\
\mathbf{4 4 0} \text { kDa } \\
\text { TOB/SAM: Tob55/Sam50; } \\
\text { Sam37, Sam35; } \\
\text { Mdm10 } \\
\mathbf{2 0 0 ~ k D a} \\
\text { TOB/SAM: Tob55/Sam50; } \\
\text { Sam37, Sam35 }\end{array}$ & $\begin{array}{l}\text { > } 600 \text { kDa } \\
\text { TOB/SAM: Tob55/Sam50; Sam37, } \\
\text { Sam35 } \\
\mathbf{2 0 0 ~ k D a} \\
\text { TOB/SAM: Tob55/Sam50; Sam37, } \\
\text { Sam35; } \\
\text { Mdm10 } \\
\mathbf{1 4 0} \text { kDa } \\
\text { TOB/SAM: Tob55/Sam50; Sam37, } \\
\text { Sam35 }\end{array}$ & $\begin{array}{l}\text { > } 700 \text { kDa } \\
\text { TOB/SAM: Tob55/Sam50; } \\
\text { Sam37, Sam35; mitofilin } \\
\text { 250 kDa } \\
\text { TOB/SAM: Tob55/Sam50; } \\
\text { Sam37, Sam35 }\end{array}$ & $\begin{array}{l}\text { > 650kDa } \\
\text { TOB/SAM: Tob55/Sam50; } \\
\text { Sam37, Sam35; } \\
\text { Tom40; } \\
\text { mitofilin* } \\
\mathbf{1 6 0} \text { kDa } \\
\text { Tob55/Sam50; } \\
\text { Mdm10; } \\
\text { mitofilin* }\end{array}$ \\
\hline
\end{tabular}

The detected variants of the $D$. discoideum TOB/SAM complex correspond to the monomeric variant of the complex composed of the main subunits $(160 \mathrm{kDa})$ and the form interacting with other proteins $(600 \mathrm{kDa})$. A monomeric variant of comparable size has been reported for S. cerevisiae (Waizenegger et al., 2004; Yamano et al., 2010; Qiu et al., 2013), N. crassa (Lackey et al., 2011; Klein et al., 2012) and human cells (Kozjak-Pavlovic et al., 2007; Ott et al., 2012) (Table 3). Importantly, the variant of the $D$. discoideum complex does not contain metaxin. As the protein is detected by anti-metaxin-1 antibody (Fig. 3), it might be assumed that this form is missing a counterpart of Tob37/Sam37 (Sokol et al., 2014), although may contain subunits still not detected. Tob37/Sam37 has been shown to be not essential and to act at the late stages of $\beta$-barrel assembly by assisting protein release from the complex (Chan \& Lithgow, 2008; Dukanovic et al., 2009). Accordingly, in S. cerevisiae and $N$. crassa, mitochondria variants missing the Tob37/ Sam37 protein have been also detected (Waizenegger et
A.
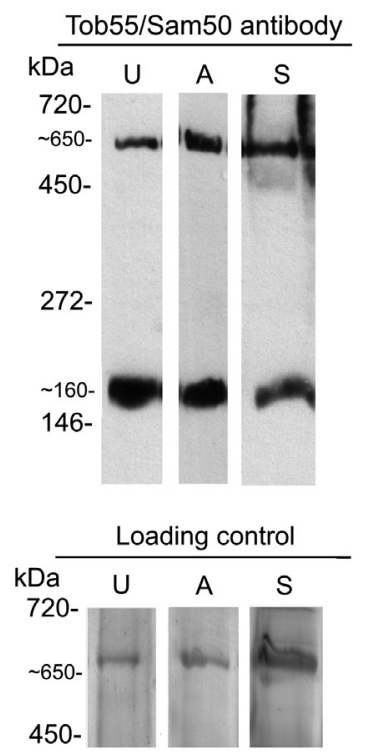

B.
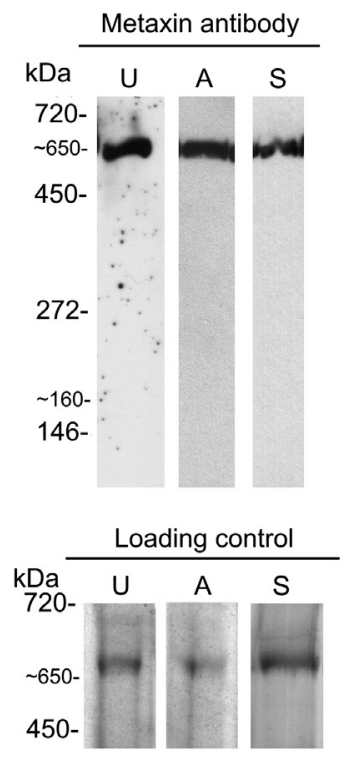

Figure 4. Estimation of the $D$. discoideum TOB/SAM complex forms in mitochondria of single cells, as well as cells from the early multicellular stages.

Mitochondria solubilized in the presence of $1.25 \%$ digitonin were separated by BN-PAGE and the obtained Western blots were immunodecorated by Tob55/Sam50 and metaxin antibody. The data presented are typical for 3 independent experiments. (U) unicellular; (A) aggregation; (S) streams. Loading control - a $650 \mathrm{kDa}$ complex band shown on part of a Coomassie stained BN gel. al., 2004; Lackey et al., 2011). Furthermore, it has been reported that in the human mitochondria, Tob55/Sam50 and metaxins seemed to be present in different complexes (Kozjak-Pavlovic et al., 2007). On the other hand, the D. discoideum form contains Mdm10 which is not present in the human mitochondria but is also detected in the forms of the TOB/SAM complex present in N. crassa (Lackey et al., 2011; Klein et al., 2012) and S. cerevisiae (Waizenegger et al., 2004; Yamano et al., 2010; Qiu et al., 2013) mitochondria, although data concerning the size of the resulting complexes are not consistent.

The $600 \mathrm{kDa}$ form of the TOB/SAM complex corresponds to the $600-700 \mathrm{kDa}$ supercomplex detected for S. cerevisiae (Qiu et al., 2013; Wenz et al., 2015) and human cells (Kozjak-Pavlovic et al., 2007; Ott et al., 2012). In the case of $S$. cerevisiae mitochondria, the 650-700 $\mathrm{kDa}$ supercomplex has been shown to contain the TOM complex interacting with the TOB/SAM complex and to promote substrate channeling in the $\beta$-barrel pathway (Qiu et al., 2013; Wenz et al., 2015) (Table 3). Thus, the presence of Tom40 in the $600 \mathrm{kDa} D$. discoideum form could be considered in two aspects. Firstly, Tom40 is the most abundant subunit of the TOM complex (Sirrenberg et al., 1997). As the molecular weight of the $D$. discoideum TOM complex has been estimated to be about $430 \mathrm{kDa}$ (Wojtkowska et al., 2015), it can be assumed that the 600 $\mathrm{kDa}$ form may represent the supercomplex consisting of the TOB/SAM $(160 \mathrm{kDa})$ and the TOM complex. Secondly, Tom 40 being the $\beta$-barrel protein itself is imported by the TOB/SAM complex. Thus, its presence in the form of the TOB/SAM complex may also reflect its import process. However,Tom 40 has not been detected in the $600-700 \mathrm{kDa}$ complexes in human mitochondria.

The presence of mitofilin/Mic60, a key component of the MICOS complex (Harner et al., 2011; Malsburg et al., 2011; Eydt et al., 2017), in the $600 \mathrm{kDa}$ form of the $D$. discoideum TOB/SAM complex at the U stage, appears to confirm the interaction between the protein and the main subunits of the TOB/SAM complex. This interaction has been shown for $S$. cerevisiae and human mitochondria (e.g. Ott et al., 2012; Rampelt et al., 2017) and is regarded to be mediated by Tob55/Sam50 (Ott et al., 2012; Xie et al.,2007; Ding et al., 2015) and/or metaxin (Xie et al., 2007). Accordingly, the yeast homologue of mitofilin/Mic60, termed Fcj1, has been shown to be important for association of the TOB/SAM complex with mitochondrial contact sites, resulting in stabilization of crista junctions in close proximity to the outer membrane (Korner et al., 2012). In addition, the TOB/ SAM complex is also described as an anchor for the MICOS complex subunits (Harner et al., 2011). Moreover, the presence of mitofilin/Mic60 in the $600 \mathrm{kDa}$ vari- 
ant of the $D$. discoideum TOB/SAM complex, may result from the protein interaction with the TOM complex, as proposed for S. cerevisiae (Qiu et al., 2013; Rampelt at al., 2017), but not observed for human mitochondria. Thus, it can be assumed that the interaction of the TOB/SAM complex with the MICOS complex may occur at the $\mathrm{U}$ stage mitochondria and may include the TOB/SAM complex interaction with the TOM complex.

In summary, the detected forms of the $D$. discoideum TOB/SAM complex, i.e. the 160 and $600 \mathrm{kDa}$ forms, appear to be similar to the forms found in S. cerevisiae, N. crassa and human mitochondria. The $600 \mathrm{kDa}$ form seems to differentiate between unicellular and early multicellular stages by putative interaction with the MICOS complex subunit, although the next stages of the $D$. discoideum life cycle should be studied to observe more spectacular differences in the TOB/SAM complex forms.

\section{Other acknowledgement}

We would like to thank Arkadiusz Urbański, Ph.D. from the Department of Animal Physiology and Development, Faculty of Biology, AMU Poznań for technical support in preparing $D$. discoideum photos from light microscope. The equipment used was sponsored in part by the Centre for Preclinical Research and Technology (CePT), a project co-sponsored by European Regional Development Fund and Innovative Economy, The National Cohesion Strategy of Poland.

\section{REFERENCES}

Bradford MM (1976) A rapid and sensitive method for the quantitation of microgram quantities of protein utilizing the principle of protein-dye binding. Anal Biochem 72: 248-254. https://doi. org/10.1016/0003-2697(76)90527-3

Buczek D, Wojtkowska M, Suzuki Y, Sonobe S, Nishigami Y, Antoniewicz M, Kmita H, Makałowski W (2016) Protein import complexes in the mitochondrial outer membrane of Amoebozoa representatives. BMC Genomics 17: 99. https://doi.org/10.1186/s12864-0162402-2

Chan NC, Lithgow T (2008) The peripheral membrane subunits of the SAM complex function codependently in mitochondrial outer membrane biogenesis. Mol Biol Cell 19: 126-136. https://doi. org /10.1091/mbc.e07-08-0796

Czarna M, Mathy G, Mac'Cord A, Dobson R, Jarmuszkiewicz W, Sluse-Goffart CM, Leprince P, De Pauw E, Sluse FE (2010) Dynamics of the Dictyostelium discoideum mitochondrial proteome during vegetative growth, starvation and early stages of development. Proteomics 10: 6-22. https://doi.org/10.1002/pmic.200900352

Ding C, Wu Z, Huang L, Wang Y, Xue J, Chen S, Deng Z, Wang L, Song Z, Chen S (2015) Mitofilin and CHCHD6 physically interact with Sam50 to sustain cristae structure. Sci Rep 5: 16064. https:// doi.org/10.1038/srep16064

Dukanovic J, Dimmer KS, Bonnefoy N, Krumpe K, Rapaport D (2009) Genetic and functional interactions between the mitochondrial outer membrane proteins Tom6 and Sam37. Mol Cell Biol 29: 5975-5988. https://doi.org/10.1128/MCB.00069-09

Eichinger L, Pachebat JA, Glöckner G, Rajandream MA, Sucgang R, Berriman M, Song J, Olsen R, Szafranski K, Xu Q, Tunggal B, Kummerfeld S, Madera M, Konfortov BA, Rivero F, Bankier AT, Lehmann R, Hamlin N, Davies R, Gaudet P, Fey P, Pilcher K, Chen G, Saunders D, Sodergren E, Davis P, Kerhornou A, Nie X, Hall N, Anjard C, Hemphill L, Bason N, Farbrother P, Desany B, Just E, Morio T, Rost R, Churcher C, Cooper J, Haydock S, van Driessche N, Cronin A, Goodhead I, Muzny D, Mourier T, Pain A, Lu M, Harper D, Lindsay R, Hauser H, James K, Quiles M, Madan Babu M, Saito T, Buchrieser C, Wardroper A, Felder M, Thangavelu M, Johnson D, Knights A, Loulseged H, Mungall K, Oliver K, Price C, Quail MA, Urushihara H, Hernandez J, Rabbinowitsch E, Steffen D, Sanders M, Ma J, Kohara Y Sharp S, Simmonds M, Spiegler S, Tivey A, Sugano S, White B, Walker D, Woodward J, Winckler T, Tanaka Y, Shaulsky G, Schleicher M, Weinstock G, Rosenthal A, Cox EC, Chisholm RL, Gibbs R, Loomis WF, Platzer M, Kay RR, Williams J, Dear PH, Noegel AA, Barrell B, Kuspa A (2005) The genome of the social amoeba Dictyostelium discoideum. Nature 435: 43-57. https://doi.org/10.1038/nature03481
Endo T, Yamano K (2010) Transport of proteins across or into the mitochondrial outer membrane. Biochim Biophys Acta 1803: 706-704. https://doi.org/10.1016/j.bbamcr.2009.11.007

Eydt, K, Davies KM, Behrendt C, Wittig I, Reichert AS (2017) Cristae architecture is determined by an interplay of the MICOS complex and the $F_{1} F_{0}$ ATP synthase via Mic27 and Mic10. Microb Cell 4: 259-272. https://doi.org/10.15698/mic2017.08.585

Fey P, Kowal AS, Gaudet P, Pilcher KE, Chisholm RL (2007) Protocols for growth and development of Dictyostelium discoideum. Nat Protoc 2: 1307-1316. https://doi.org/10.1038/nprot.2007.178

Flinner N, Ellenrieder L, Stiller SB, Becker T, Schleiff E, Mirus O (2013) Mdm10 is an ancient eukaryotic porin co-occurring with the ERMES complex. Biochim Biophys Acta 1833: 3314-3325. https:// doi.org/10.1016/j.bbamcr.2013.10.006

Flowers JM, Li SI, Stathos A, Saxer G, Ostrowski EA, Queller DC, Strassmann JE, Purugganan MD (2010) Variation, Sex, and Social Cooperation: Molecular Population Genetics of the social amoeba Dictyostelium discoideum. PLoS Genet 6: e1001013. https://doi. org/10.1371/journal.pgen.1001013

Harner M, Körner C, Walther D, Mokranjac D, Kaesmacher J, Welsch U, Griffith J, Mann M, Reggiori F, Neupert W (2011) The mitochondrial contact site complex, a determinant of mitochondrial architecture. EMBO J 30: 4356-4370. https://doi.org/doi:10.1038/ emboj.2011.379

Höhr AIC, Lindau C, Wirth C, Qiu J, Stroud DA, Kutik S, Guiard B, Hunte C, Becker T, Pfanner N, Wiedemann N (2018) Membrane protein insertion through a mitochondrial $\beta$-barrel gate. Science 359: eaah6834. https://doi.org/10.1126/science.aah6834

Klein A, Israel L, Lackey SWK, Nargang FE, Imhof A, Baumeister W, Neupert W, Thomas DR (2012) Characterization of the insertase for $\beta$-barrel proteins of the outer mitochondrial membrane. J Cell Biol 199: 599-611. https://doi.org/10.1083/jcb.201207161

Körner C, Barrera M, Dukanovic J, Eydt K, Harner M, Rabl R, Vogel F, Rapaport D, Neupert W, Reichert AS (2012) The C-terminal domain of Fcj1 is required for formation of crista junctions and interacts with the TOB/SAM complex in mitochondria. Mol Biol Cell 23: 2143-2155. https://doi.org/10.1091/mbc.E11-10-0831

Kornmann B, Currie E, Collins SR, Schuldiner M, Nunnari J, Weissman JS, Walter P (2009) An ER-mitochondria tethering complex revealed by a synthetic biology screen. Science 325: 477-481. https:// doi.org/10.1126/science.1175088

Kozjak-Pavlovic V, Ross K, Benlasfer N, Kimming S, Karlas A, Rudel $\mathrm{T}$ (2007) Conserved roles of Sam50 and metaxins in VDAC biogenesis. EMBO Rep 8: 576-582. https://doi.org/10.1038/ sj.embor. 7400982

Lackey SW, Wideman JG, Kennedy EK, Go NE, Nargang FE (2011) The Neurospora crassa TOB complex: analysis of the topology and function of Tob38 and Tob37. PLoS One 6: e25650. https://doi. org/10.1371/journal.pone.0025650

Laemmli UK (1970) Cleavage of structural proteins during the assembly of the head of bacteriophage T4. Nature 227: 680-685. https:// doi.org/10.1038/227680a0

von der Malsburg K, Müller JM, Bohnert M, Oeljeklaus S, Kwiatkowska P, Becker T, Loniewska-Lwowska A, Wiese S, Rao S, Milenkovic D, Hutu DP, Zerbes RM, Schulze-Specking A, Meyer HE, Martinou JC, Rospert S, Rehling P, Meisinger C, Veenhuis M, Warscheid B, van der Klei IJ, Pfanner N, Chacinska A, van der Laan M (2011) Dual role of mitofilin in mitochondrial membrane organization and protein biogenesis. Dev Cell 21: 694-707. https://doi.org/10.1016/j. devcel.2011.08.026

Neupert W (2015) A perspective on transport of proteins into mitochondria: a myriad of open questions. J Mol Biol 427: 1135-1158. https://doi.org/10.1016/j.jmb.2015.02.001

Ott C, Ross K, Straub S, Thiede B, Götz M, Goosmann C, Krischke M, Mueller MJ, Krohne G, Rudel T, Kozjak-Pavlovic V (2012) Sam50 functions in mitochondrial intermembrane space bridging and biogenesis of respiratory complexes. Mol Cell Biol 32: 11731188. https://doi.org/10.1128/MCB.06388-11

Ott C, Dorsch E, Fraunholz M, Straub S, Kozjak-Pavlovic V (2015) Detailed analysis of the human mitochondrial contact site complex indicate a hierarchy of subunits. PLOS One 10: e0120213. https:// doi.org/10.1371/journal.pone.0120213

Pfanner N, Warscheid B, Wiedemann N (2019) Mitochondrial proteins: from biogenesis to functional networks. Nat Rev Mol Cell Biol 20: 267-284. https://doi.org/10.1038/s41580-018-0092-0

Qiu J, Wenz LS, Zerbes RM, Oeljeklaus S, Bohnert M, Stroud DA, Wirth C, Ellenrieder L, Thornton N, Kutik S, Wiese S, SchulzeSpecking A, Zufall N, Chacinska A, Guiard B, Hunte C, Warscheid B, van der Laan M, Pfanner N, Wiedemann N, Becker T (2013) Coupling of mitochondrial import and export translocases by receptor-mediated supercomplex formation. Cell 154: 596-608. https:// doi.org/10.1016/j.cell.2013.06.033

Rampelt H, Bohnert M, Zerbes RM, Horvath SE, Warscheid B, Pfanner N, van der Laan M (2017) Mic10, a core subunit of the mitochondrial contact site and cristae organizing system, interacts with 
the dimeric $\mathrm{F}_{1} \mathrm{~F}_{0}$-ATP synthase. J Mol Biol 429: 1162-1170. https:// doi.org/10.1016/j.jmb.2017.03.006

Sirrenberg C, Endres M, Becker K, Bauer MF, Walther E, Neupert W, Brunner M (1997) Functional cooperation and stoichiometry of protein translocases of the outer and inner membranes of mitochondria. J Biol Chem 272: 29963-29966. https://doi.org/10.1074/ jbc. 272.47 .29963

Slocinska M, Antos-Krzeminska N, Rosinski G, Jarmuszkiewicz W (2011) Identification and characterization of uncoupling protein 4 in fat body and muscle mitochondria from the cockroach Gromphadorbina cocquereliana. J Bioenerg Biomembr 43: 717-727. https://doi. org/10.1007/s10863-011-9385-0

Sokol AM, Sztolsztener ME, Wasilewski M, Heinz E, Chacinska A (2014) Mitochondrial protein translocases for survival and wellbeing. FEBS Lett 588: 2484-2495. https://doi.org/10.1016/j.febslet.2014.05.028

Waizenegger T, Habib SJ, Lech M, Mokranjac M, Paschen SA, Hell K, Neupert W, Rapaport D (2004) Tob38, a novel essential component in the biogenesis of $\beta$-barrel proteins of mitochondria. EMBO Rep 5: 704-709. https://doi.org/10.1038/sj.embor.7400183

Wenz LS, Ellenrieder L, Qiu J, Bohnert M, Zufall N, van der Laan M, Pfanner N, Wiedemann N, Becker T (2015) Sam37 is crucial for formation of the mitochondrial TOM-SAM supercomplex, thereby promoting $\beta$-barrel biogenesis. J Cell Biol 210: 1047-1054. https:// doi.org/10.1083/jcb.201504119

Witting I, Braun H, Schägger H (2006) Blue native PAGE. Nat Protoc 1: 418-428. https://doi.org/10.1038/nprot.2006.62
Wojtkowska M, Jakalski M, Pieńkowska JR, Stobienia O, Karachitos A, Przytycka TM, Weiner J, 3rd, Kmita H, Makałowski W (2012) Phylogenetic analysis of mitochondrial outer membrane $\beta$-barrel channels. Genome Biol Evol 4: 110-125. https://doi.org/10.1093/ gbe/evr130

Wojtkowska M, Buczek D, Stobienia O, Karachitos A, Antoniewicz M, Slocinska M, Makałowski W, Kmita H (2015) The TOM complex of amoebozoans: the cases of the amoeba Acanthamoeba castellanii and the slime mold Dictyostelium discoideum. Protist 166: 349-362. https://doi.org/10.1016/j.protis.2015.05.005

Wojtkowska M, Buczek D, Suzuki Y, Shabardina V, Makałowski W, Kmita H (2017) The emerging picture of the mitochondrial protein import complexes of Amoebozoa supergroup. BMC Genomics 18: 997. https://doi.org/10.1186/s12864-017-4383-1

Xie J, Marusich MF, Souda P, Whitelegge J, Capaldi RA (2007) The mitochondrial inner membrane protein Mitofilin exists as a complex with SAM50, metaxins 1 and 2, coiled-coil-helix coiled-coil-helix domain-containing protein 3 and 6 and DnaJC11. FEBS Lett 581: 3545-3549. https://doi.org/10.1016/j.febslet.2007.06.052

Yamano K, Tanaka-Yamano S, Endo T (2010) Mdm10 as a dynamic constituent of the TOB/SAM complex directs coordinated assembly of Tom40. EMBO Rep 11: 187-193. https://doi.org/10.1038/ embor.2009.283

Yang RF, Zhao GW, Liang ST, Zhang Y, Sun LH, Chen HZ, Liu DP (2012) Mitofilin regulates cytochrome c release during apoptosis by controlling mitochondrial cristae remodeling. Biochem Biophys Res Commun 428: 93-98. https://doi.org/10.1016/j.bbrc.2012.10.012 